УДК 656.25

\title{
ФУНКЦИОНИРОВАНИЕ СИСТЕМ УПРАВЛЕНИЯ БЕЗОПАСНОСТЬЮ ДВИЖЕНИЯ НА ЖЕЛЕЗНЫХ ДОРОГАХ УКРАИНЫ И РОССИИ
}

Доктора техн. наук А.Н. Огарь, Ю.О. Пазойский, кандидаты техн. наук А.В. Розсоха, А.А. Сидраков, соискатель науч. степени Ю.В. Смачило

\section{ФУНКЦІОНУВАННЯ СИСТЕМ УПРАВЛІННЯ БЕЗПЕКОЮ РУХУ НА ЗАЛІЗНИЦЯХ УКРАЇНИ ТА РОСІї}

Доктори техн. наук О.М. Огар, Ю.О. Пазойський, кандидати техн. наук О.В. Розсоха, О.А. Сідраков, здобувач наук. ступеня Ю.В. Смачило

\section{THE FUNCTIONING OF SYSTEMS OF MANAGEMENT OF SAFETY OF TRAFFIC ON THE RAILWAYS OF UKRAINE AND RUSSIA}

Doctors of technical sciences A. Ogar, Y. Pazoysky, Doctor of Science (Ph.D.) A. Rozsokha, A. Sydrakov, Applicant of the scientific degree Y. Smachilo

Проведено аналіз функиіонування систем управління безпекою руху поїздів на залізницях України і Росії. Управління безпекою руху вимагає нових підходів та методологій, реалізачія яких повинна внести суттєві корективи в нині чинну систему управління безпекою перевезень. У висновку наведені приклади таких методологій, які в даний час є актуальними для Украӥни.

Ключові слова: безпека руху поӥздів, система управління безпекою руху, ефективність роботи залізниць.

Проведен анализ функиионирования систем управления безопасностью движения поездов на железных дорогах Украины и России. Управление безопасностью движения требует новых подходов и методологий, реализачия которых должна внести существенные коррективы в ныне действуюшую систему управления безопасностью перевозок. В заключении приведены примеры таких методологий, которые в настоящее время являются актуальныли для Украины.

Ключевые слова: безопасность движения поездов, система управления безопасностью движения, эффективность работы железных дорог.

The analysis of functioning of systems of management of safety of movement of trains on the Railways of Ukraine and Russia. Analyzing the frequency of transport events occurring on railway transport of Ukraine, we can say that showing positive dynamics to reduce the number of accidents. But it should be noted that under the present system, ensure the safe movement of trains and although there is a slight decline in the number of traffic accidents, but the losses are higher in this case. The existing regulatory framework Railways of Ukraine requires comparison with foreign standards and the subsequent establishment of uniformity with regard to the peculiarities of the country. For example, international standards RAMS and innovative methodology STMS on the Ukrainian Railways should be developed and implemented its own information security management system of trains. Is the actual implementation of systems for decision support based on assessment of risk. The experience of Russia and countries of European Union development methodologies security must be supported by normative-methodical documents.

Keywords: traffic safety of trains, the system of management of safety of traffic, the efficiency of Railways.

Вступление. Железнодорожный транспорт - одна из важнейших отраслей экономики любой страны. Он обеспечивает потребности хозяйства и населения в перевозках, а также является крупнейшей составляющей частью материально-технической базы страны.

Значительный рост конкуренции в транспортной сфере вынуждает железные дороги сфокусироваться на развитии данной 
отрасли и повышении еe конкурентоспособности. При этом повышение безопасности движения поездов является одной из важнейших неотъемлемых задач отрасли.

В последнее десятилетие железные дороги стран «пространства 1520» продолжают активное реформирование железнодорожного сектора. И, безусловно, реформы и изменения, происходящие на железнодорожном транспорте, не могли не повлиять на повышение безопасности движения поездов.

В Транспортной стратегии Украины на период до 2020 года [1] и Стратегии развития железнодорожного транспорта в Российской Федерации до 2030 года [2] говорится, что уровень безопасности не соответствует современным требованиям. Таким образом, вопросы обеспечения безопасности движения поездов являются весьма актуальными.

Анализ литературных данных и постановка проблемы. Вопросами безопасности движения поездов и развитием теории расчета показателей надежности работы железнодорожного транспорта занимались такие ученые, как Бутько Т.В., Болотный В.Я., Грау Б., Грунтов П.С., Жуковицкий И.В., Загарий Г.И., Замышляев А.М., Кобзев В.А., Кочнев Ф.П., Лисенков В.М., Модин Н.К., Негрей В.Я., Образцов В.Н., Правдин Н.В., Сапожников В.В., Сотников И.Б., Стефанов М.Я., Страковский И.И., Шабалин М.Г. и др. [3-5].

\section{Профессором} безопасности отдельных составляющих технологических процессов, выполнена четкая классификация методов и способов обеспечения безопасности [4].

Профессор Замышляев А.М. внес значительный вклад в вопрос повышения безопасности движения на железнодорожном транспорте с использованием современных информационных технологий, что отразилось в создании им системы УРРАН [6].

Анализируя исследования указанных ученых, следует отметить, что подходы по определению уровня безопасности движения на железнодорожном транспорте были в основном направлены на получение результата по отдельной группе показателей. Комплексной оценке системы управления безопасностью движения поездов внимания в основном не уделялось.
Цели и задачи исследования. Целью данной работы является определение способов повышения эффективности функционирования железнодорожного транспорта путем комплексной оценки состояния безопасности движения поездов. Для этого необходимо проанализировать функционирование систем управления безопасностью движения поездов на железных дорогах Украины и России.

Функционирование системы управления безопасностью движения поездов железных дорог. Согласно утвержденного Министерством инфраструктуры Украины Положения о системе управления безопасностью движения поездов в Государственной администрации железнодорожного транспорта Украины [3], безопасность движения - это состояние защищенности движения железнодорожного подвижного состава, которое характеризуется отсутствием предельного риска возникновения транспортных происшествий и их последствий, которые могут причинить вред жизни и здоровью граждан, окружающей среде, имуществу физических или юридических лиц.

В вышеуказанном положении говорится, что система управления безопасностью движения поездов - комплекс мероприятий, позволяющих персоналу Укрзализныци, железных дорог, предприятий и их структурных подразделений эффективно проводить работу в сфере страхования движения поездов.

Общее количество транспортных происшествий на железных дорогах Украины, а также размер причиненных ими убытков с учетом инфляции [7] приведены на рис 1. Максимальными годами убыточности с 1995 по 2014 гг. являются 1996, 2001 и 2007 гг. Несмотря на положительную динамику уменьшения транспортных происшествий, количество причиненных ими убытков возрастает и в 2014 году составило 7525,72 тыс. грн (около 915 тыс. дол. США). Причиной указанных убытков являются транспортные происшествия, приведенные на рис. 2.

Анализ безопасности движения за 2014 года свидетельствует о том, что $84,7 \%$ случаев транспортных происшествий произошли по трем основным причинам: неисправность подвижного состава и элементов инфраструктуры, сход подвижного состава при маневрах и в поездах, а также неправильные действия причастных работников. 


\section{Експлуатація залізниць}

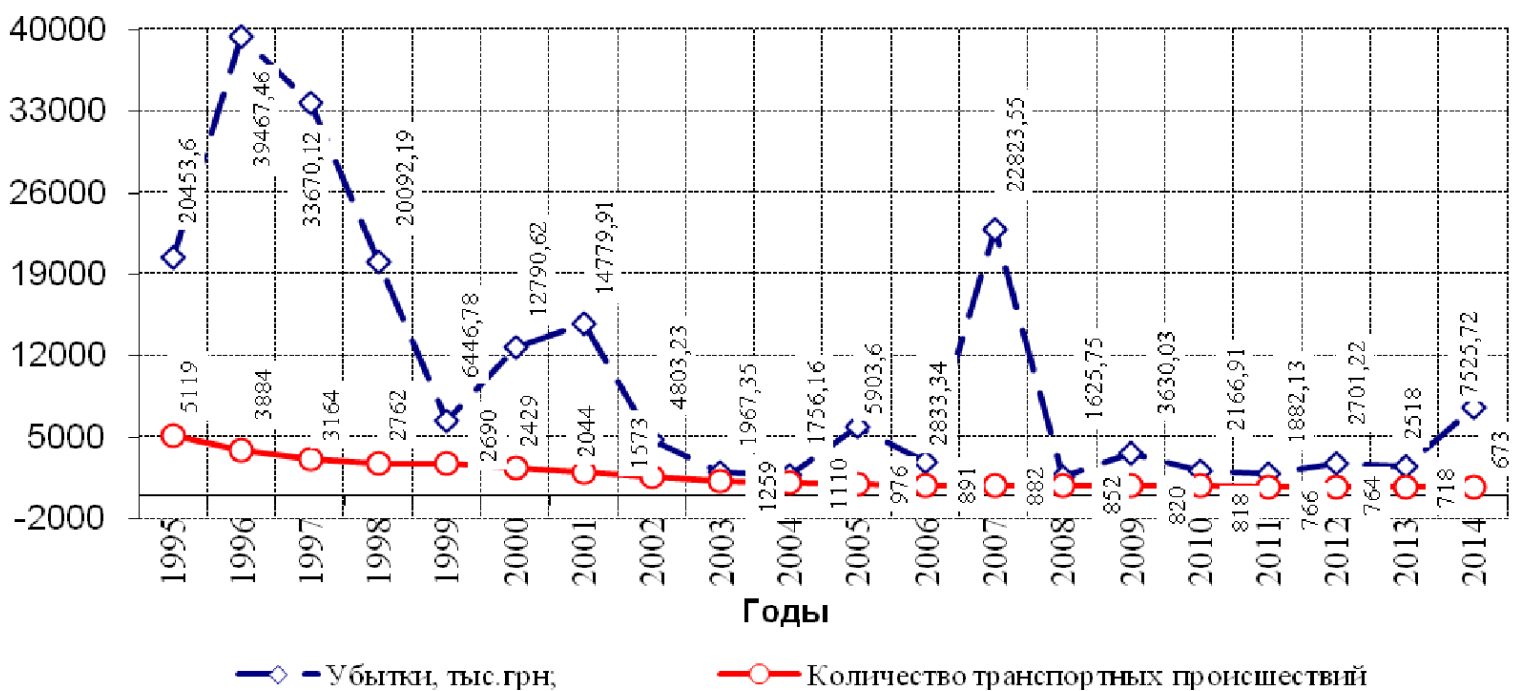

Рис. 1. Количество транспортных происшествий и размер убытков от их причинения на железных дорогах Украины

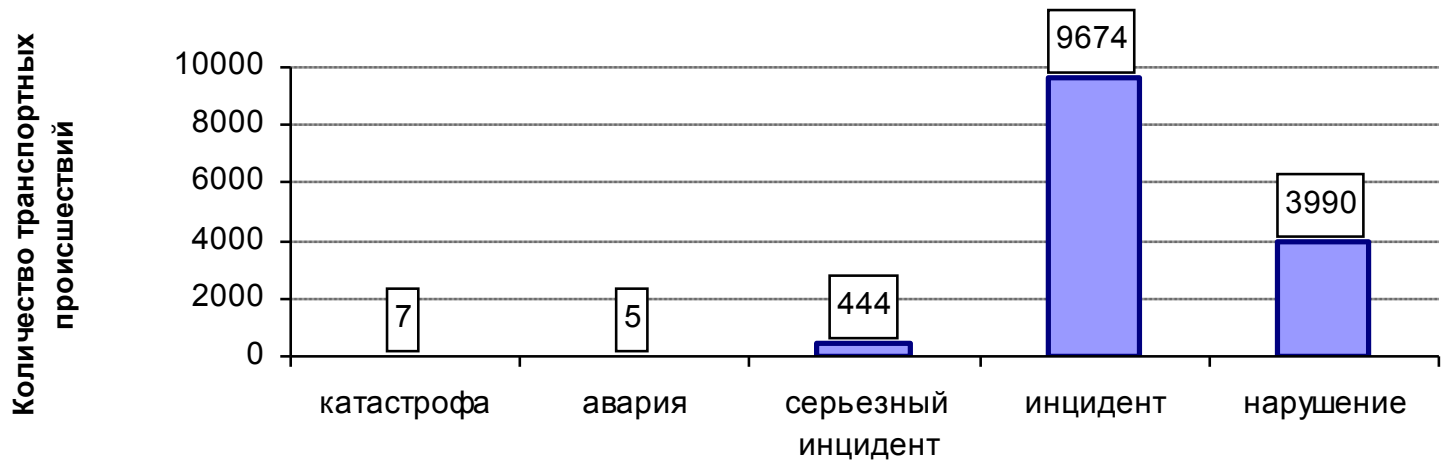

Транспортные происшествий

Рис. 2. Распределение количества транспортных происшествий по их видам на железных дорогах Украины в период с 2004 по 2014 гг.

Приведенное количество транспортных происшествий в соотношении к 100 млн ткм показано на рис. 3. За последнее десятилетие приведенное количество транспортных происшествий в соотношении к 100 млн ткм в целом сохраняется на одном уровне.

В отличие от девяностых годов двадцатого века среднее количество транспортных происшествий за сутки (рис. 4.) за последние десять лет так же стабильно и не превышает трех транспортных происшествий в сутки.

На pис. 5 приведено количество транспортных происшествий и размеры убытков от их причинения по хозяйствам Укрзализныци. Аббревиатурами обозначены следующие хозяйства: Д - перевозок; Т - локомотивное; П - путевое; В - вагонное; Ш - сигнализации и связи; Е - электроснабжения; Л - пассажирское; М - коммерческое (грузовое). Все данные о пригородном хозяйстве включены в статистику локомотивного хозяйства, поскольку транспортные происшествия в работе пригородного хозяйства напрямую связаны с функционированием подвижного состава. 


\section{Експлуатація залізниць}

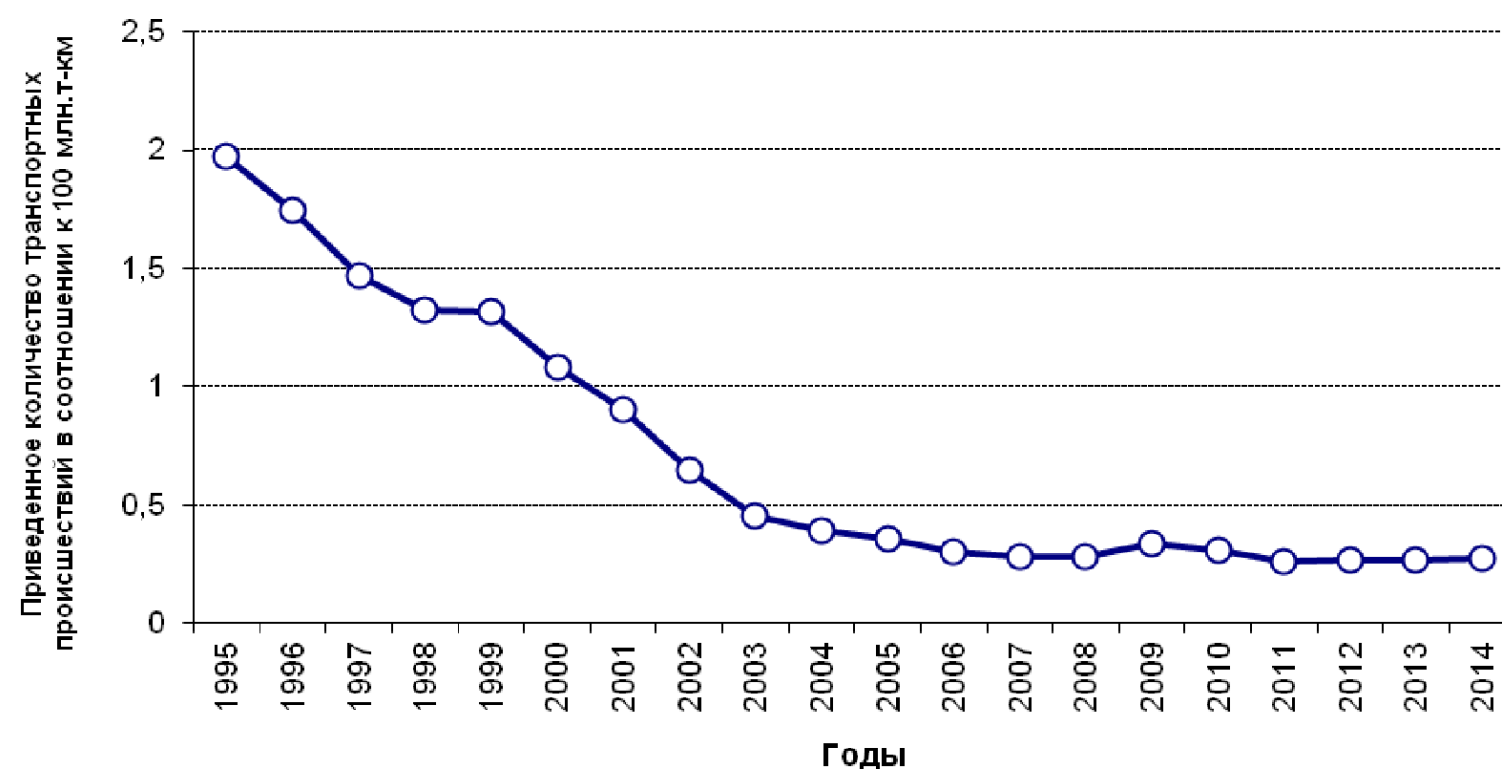

Рис. 3. Приведенное количество транспортных происшествий в соотношении к 100 млн ткм на железных дорогах Украины в период с 1995 по 2014 гг.

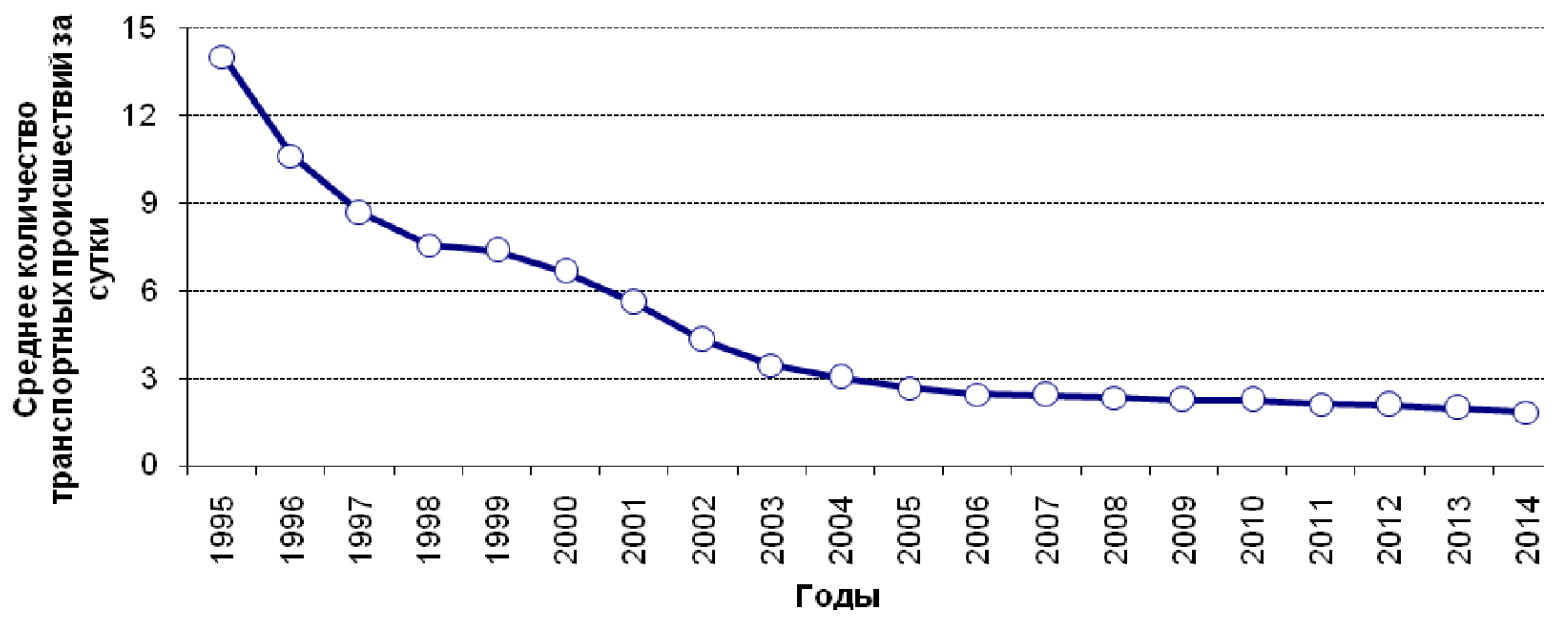

Рис. 4. Среднее количество транспортных происшествий за сутки на железных дорогах Украины с 1995 по 2014 гг.

Самые значительные убытки наблюдаются в хозяйствах П и $\mathrm{M}$, далее за ними идут хозяйства Т, В и Д.

В 2014 году почти $47 \%$ транспортных происшествий (42 случая) допущено по вине работников путевого хозяйства из-за неудовлетворительного содержания пути. В коммерческом хозяйстве самой распространенной ошибкой при возникновении транспортных происшествий является нарушение технических условий погрузки и крепления грузов.

На рис. 6,7 показано распределение транспортных происшествий по хозяйствам украинских железных дорог. 


\section{Експлуатація залізниць}

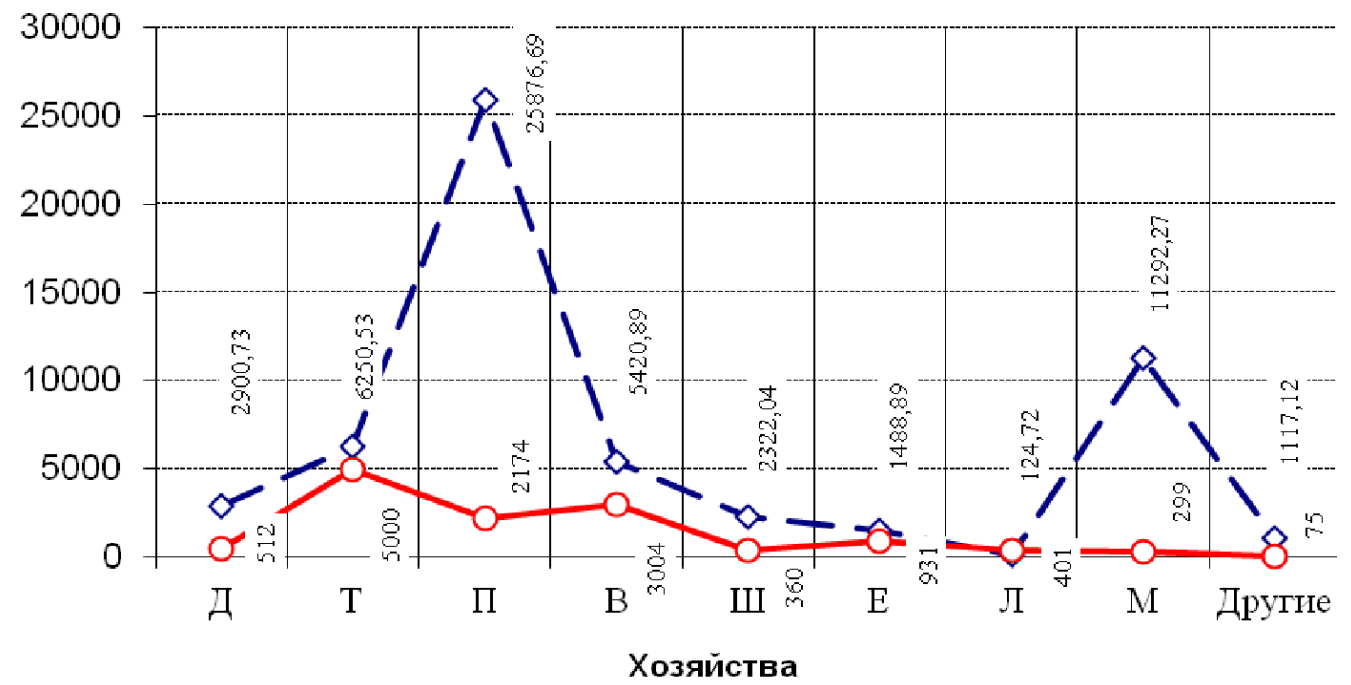

- Убыткл, Тыс. грн

- Колнчество транспортных пр онсшествнй

Рис. 5. Количество транспортных происшествий и размеры убытков от их причинения по хозяйствам Укрзализныци за период с 2004 по 2014 гг.

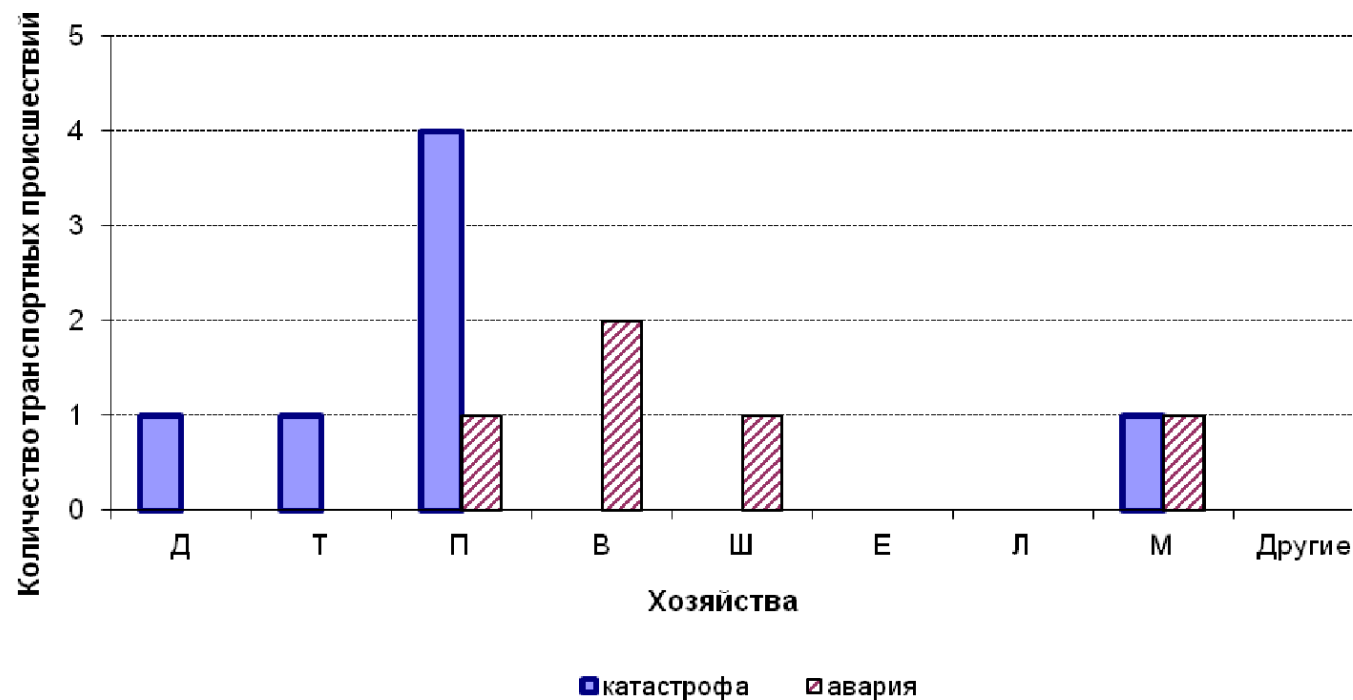

Рис. 6. Распределение количества катастроф и аварий по хозяйствам Укрзализныци за период с 2004 по 2014 гг.

Наибольшее количество катастроф произошло в путевом хозяйстве, за ним следуют хозяйства Д, Т и $\mathrm{M}$. Самый напряженный год по количеству аварий и катастроф - 2007 (три катастрофы и три аварии). С 2008 года подобных случаев не зарегистрировано.

Согласно статистике по количеству инцидентов и нарушений на первом месте располагается локомотивное хозяйство (4118 инцидентов и 1397 нарушений), за ним следует вагонное хозяйство (2377 инцидентов, 820 нарушений) и путевое хозяйство (1399 инцидентов, 762 нарушения). Наибольшее количество серьезных инцидентов произошло в путевом хозяйстве - 179 случаев. 


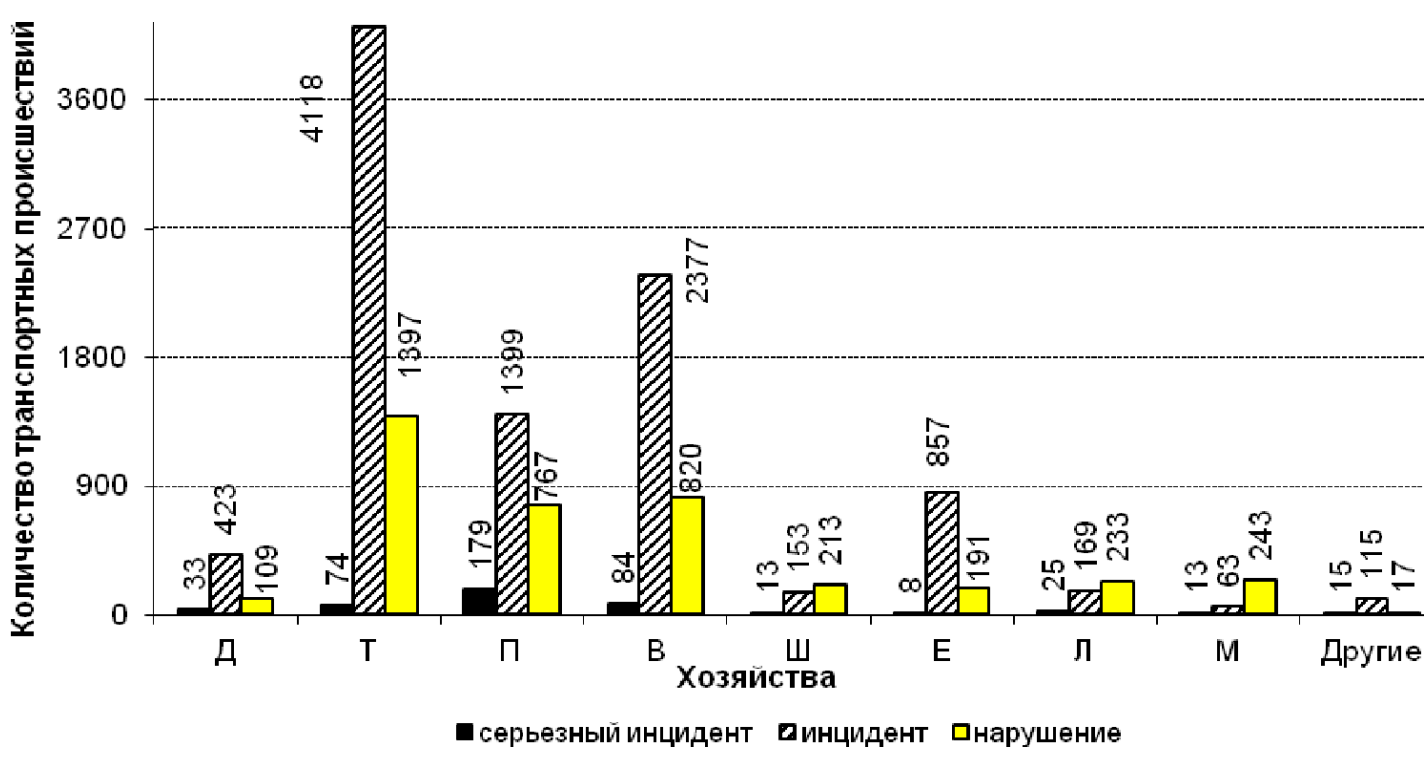

Рис. 7. Распределение количества серьезных инцидентов, инцидентов и нарушений по хозяйствам Укрзализныци за период с 2004 по 2014 гг.

В таблице указано количество транспортных происшествий, связанных с влиянием «человеческого фактора». Из общего количества транспортных происшествий за 2014 г. 471 случай, или $70 \%$, связаны с влиянием "человеческого фактора".

Таким образом, несмотря на ежегодное падение количества транспортных происшествий, ущерб от них с учетом влияния "человеческого" фактора остается практически неизменным.

На железных дорогах Российской Федерации процесс реформирования отрасли начался значительно раньше, чем на железных дорогах Украины. Как и все развитые страны, в процессе реформирования ОАО «РЖД» столкнулась с вопросом обеспечения безопасности перевозочного процесса и безаварийности работы железнодорожного транспорта.

Таблица

Количество транспортных происшествий, связанных с влиянием "человеческого фактора"

\begin{tabular}{|c|c|c|c|}
\hline Год & $\begin{array}{c}\text { Общее количество } \\
\text { транспортных происшествий }\end{array}$ & $\begin{array}{c}\text { Количество транспортных } \\
\text { происшествий, связанных с влиянием } \\
\text { "человеческого фактора" }\end{array}$ & $\begin{array}{c}\text { То же в } \\
\text { процентном } \\
\text { соотношении }\end{array}$ \\
\hline 2004 & 1110 & 888 & 80 \\
\hline 2005 & 976 & 769 & 79 \\
\hline 2006 & 891 & 711 & 80 \\
\hline 2007 & 882 & 742 & 77 \\
\hline 2008 & 852 & 657 & 79,1 \\
\hline 2009 & 820 & 649 & 79 \\
\hline 2010 & 818 & 646 & 77,8 \\
\hline 2011 & 766 & 596 & 74,5 \\
\hline 2012 & 765 & 549 & 70 \\
\hline 2013 & 718 & 535 & 77,8 \\
\hline 2014 & 673 & 471 & 7213 \\
\hline Вместе & 9271 & & \\
\hline
\end{tabular}


За последние годы достигнут достаточно высокий уровень безопасности движения (в последние годы - не более 10 крушений). Если использовать для оценки уровня безопасности количество погибших пассажиров на 1 млрд пасс./км, то в России этот показатель равен 0,026 , в Японии $-0,029$, в США - 0,29. Таким образом, уровень безопасности в РФ на порядок выше, чем в США [8].

На рис. 8 приведено количество крушений и аварий, которые произошли на сети железных дорог России за период с 1996 по 2011 гг.

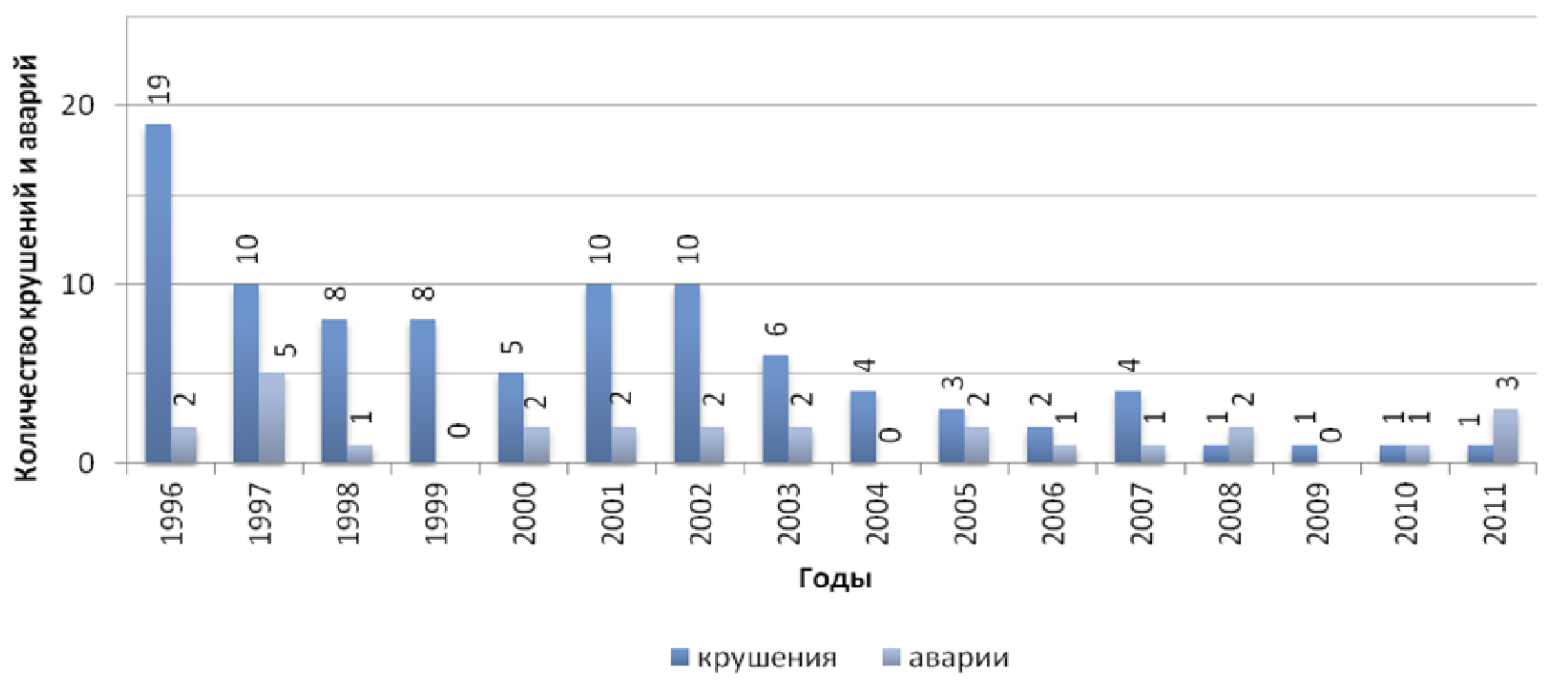

Рис. 8. Количество крушений и аварий на железных дорогах России за период с 1996 по 2011 гг.

Статистические данные ОАО «РЖД», представленные на рис. 8, демонстрируют значительное снижение количества крушений и аварий за период с 2003 по 2008 гг. В $2009-$ 2011 гг. в условиях существенного изменения географии и роста напряженности грузопотоков, формирования новой модели транспортного рынка и роста числа независимых участников перевозочного процесса снижение количества крушений и аварий замедлилось. Деятельность этих участников существенно влияет на безопасность движения поездов, но при этом слабо регламентирована и стандартизирована.

Однако результатом целенаправленной деятельности по предупреждению нарушений безопасности движения "РЖД" в 2014 году явилось снижение аварийности до значения, предусмотренного Транспортной стратегией Российской Федерации, до 2,4 события на 1 млн поездо-километров.

Но все еще основной задачей инфраструктуры железнодорожного транспорта Российской Федерации является безусловное обеспечение потребностей экономики и населения в перевозках при безусловном обеспечении безопасности движения и надежности транспортных средств.

Доля стоимости основных фондов инфраструктуры железнодорожного транспорта составляет более $60 \%$ от общей стоимости основных средств ОАО «РЖД», а доля эксплуатационных затрат на объекты инфраструктуры составляет порядка $35 \%$ от общего объема эксплуатационных затрат.

Поэтому крайне важной задачей инновационного развития ОА «РЖД» является снижение стоимости жизненного цикла объектов инфраструктуры при условии обеспечения высокого уровня надежности технических средств [9].

В европейских странах эта задача решается на основе методологии обеспечения безотказности (Reliability), готовности (Availability), ремонтопригодности (Maintainability) и безопасности (Safety) на железнодорожном транспорте - RAMS, которая нормативно определена стандартом EN 0126. Однако она не в полной мере решает задачи управления надежностью, безопасностью, 
ресурсами и не охватывает аспекты долговечности, предусмотренные российскими стандартами. Кроме того, RAMS практически не рассматривает "человеческий фактор" и не затрагивает проблемы управления затратами на содержание и модернизацию объектов инфраструктуры на этапах жизненного цикла [10].

Методология обеспечения безотказности, готовности, ремонтопригодности и безопасности приведена на рис. 9. Рост объемов перевозок грузов в России особенно наблюдается на Юго-Восточной железной дороге, которая обслуживает крупнейший промышленный регион европейской части страны, где расположены ряд крупных горнообогатительных и металлургических комбинатов, пунктов налива нефтепродуктов, крупных цементных заводов и предприятий по производству химических удобрений. В таких условиях для этих предприятий необходимо совершенствование технологии работы станции с целью предотвращения рисковых ситуаций и минимизации ущерба в случае их возникновения.

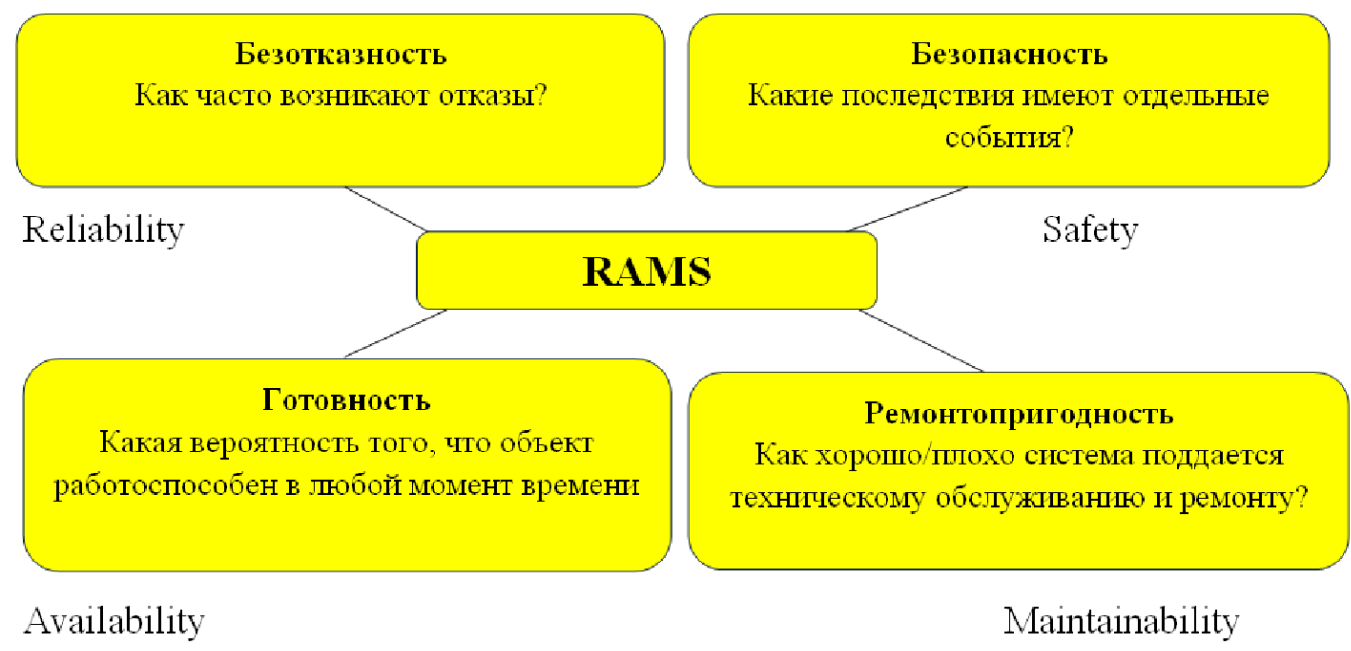

Рис. 9. Критерии системы RAMS

В связи с этим требуется создание системы предупреждения отдельных ошибок, выявления несовершенства конструкций, несоответствия технологии работ, а также их различного сочетания. Применение факторного анализа позволит преодолеть сложившиеся недостатки современной системы управления безопасностью и перейти на качественно новый уровень развития данной системы, отличительными особенностями которого будут являться установление четкой взаимосвязи между понятиями «надежность» и «безопасность» и их показателями.

В Российской Федерации совместно ОАО «РЖД» и ОАО «НИИАС» была создана новая, не имеющая аналогов, система управления ресурсами, рисками на этапах жизненного цикла на основе анализа надежности на железнодорожном транспорте - УРРАН, внедренная на железных дорогах России [6, 11].

Внедрение системы УРРАН впервые началось в 2010 г. в путевом хозяйстве
Северной железной дороги. Первые результаты были предоставлены уже в 2011 г. и стали подтверждением применимости разработанных критериев.

Методология УРРАН подкреплена нормативно-методическими документами: национальными стандартами, стандартами ОАО «РЖД», методиками.

Внедренная система поддержки принятия решений поддерживает не только непосредственно управление рисками, но и позволяет использовать результаты анализа для принятия управленческих решений.

B отличие от методологии RAMS, в системе УРРАН для оценки объектов по предельному состоянию дополнительно были добавлены такие показатели, как долговечность и живучесть. Систему управления ресурсами, рисками и надежностью на этапах жизненного цикла (УРРАН) можно наблюдать на рис. 10. 


\section{Експлуатація залізниць}

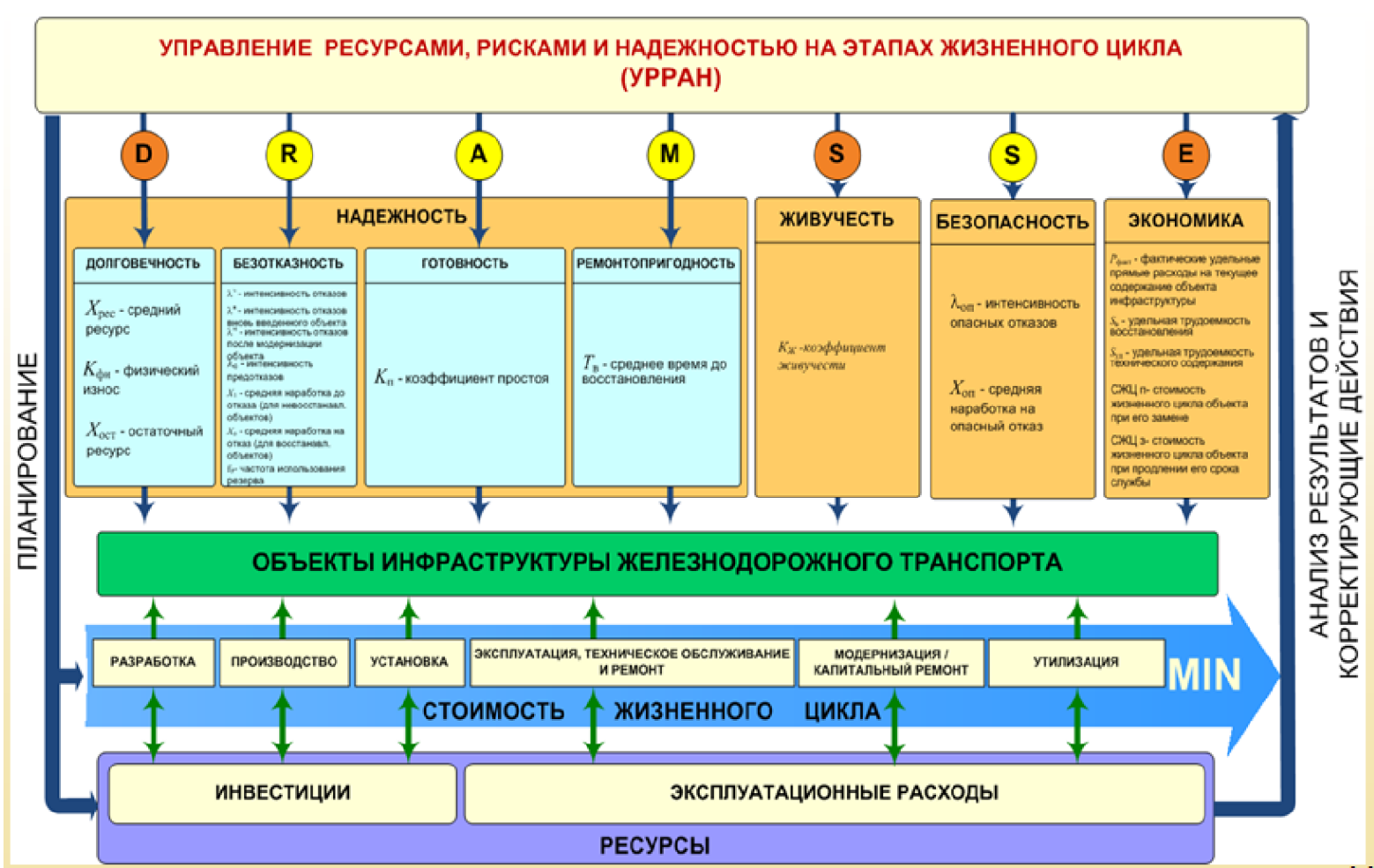

Рис. 10. Показатели системы УРРАН

Процесс управления рисками находится в непосредственной связи с управлением расходами на содержание инфраструктуры. Например, решение оптимизации жизненного цикла железнодорожного пути принимается на основе зависимости операционных затрат на техническое содержание от назначенного ресурса элементов железнодорожного пути. При этом область принятия решений о назначении вида ремонта не должна выходить за пределы допустимого уровня ресурсного риска (рис. 11) [12].

Для объективной оценки параметров надежности и корректного сопоставления различных участков пути в системе УРРАН, как и в европейской методологии, используются эталонные объекты и вводятся поправочные коэффициенты, учитывающие условия эксплуатации и конструктивные особенности верхнего строения пути. В отличие от европейских подходов при определении эталонных и стандартных объектов пути в системе УРРАН введены дополнительные поправочные коэффициенты, учитывающие пропущенный тоннаж и климатические условия эксплуатации.

Выводы. Анализируя частоту транспортных событий, происходящих в железнодорожном секторе Украины, можно отметить, что с 2003 г. наглядно видна положительная динамика по сокращению числа транспортных происшествий. Однако, просматривая тенденцию с 2004 г., можно сделать вывод, что при действующей системе обеспечения безопасности движения поездов хотя и сохраняется незначительная тенденция сокращения количества транспортных происшествий, но убытки при этом возрастают.

Существующая нормативная база железных дорог Украины требует сопоставления с иностранными стандартами и последующего формирования единообразия с учетом особенностей страны.

По примеру международных стандартов RAMS и инновационной методологии УРРАН на украинских железных дорогах также должна быть разработана и внедрена своя информационная система управления безопасностью движения поездов. Поскольку 78,7 \% транспортных происшествий на железных дорогах Украины связаны с влиянием "человеческого фактора", актуальным является внедрение систем поддержки принятия решений, построенных на оценке риска. 


\section{Експлуатація залізниць}

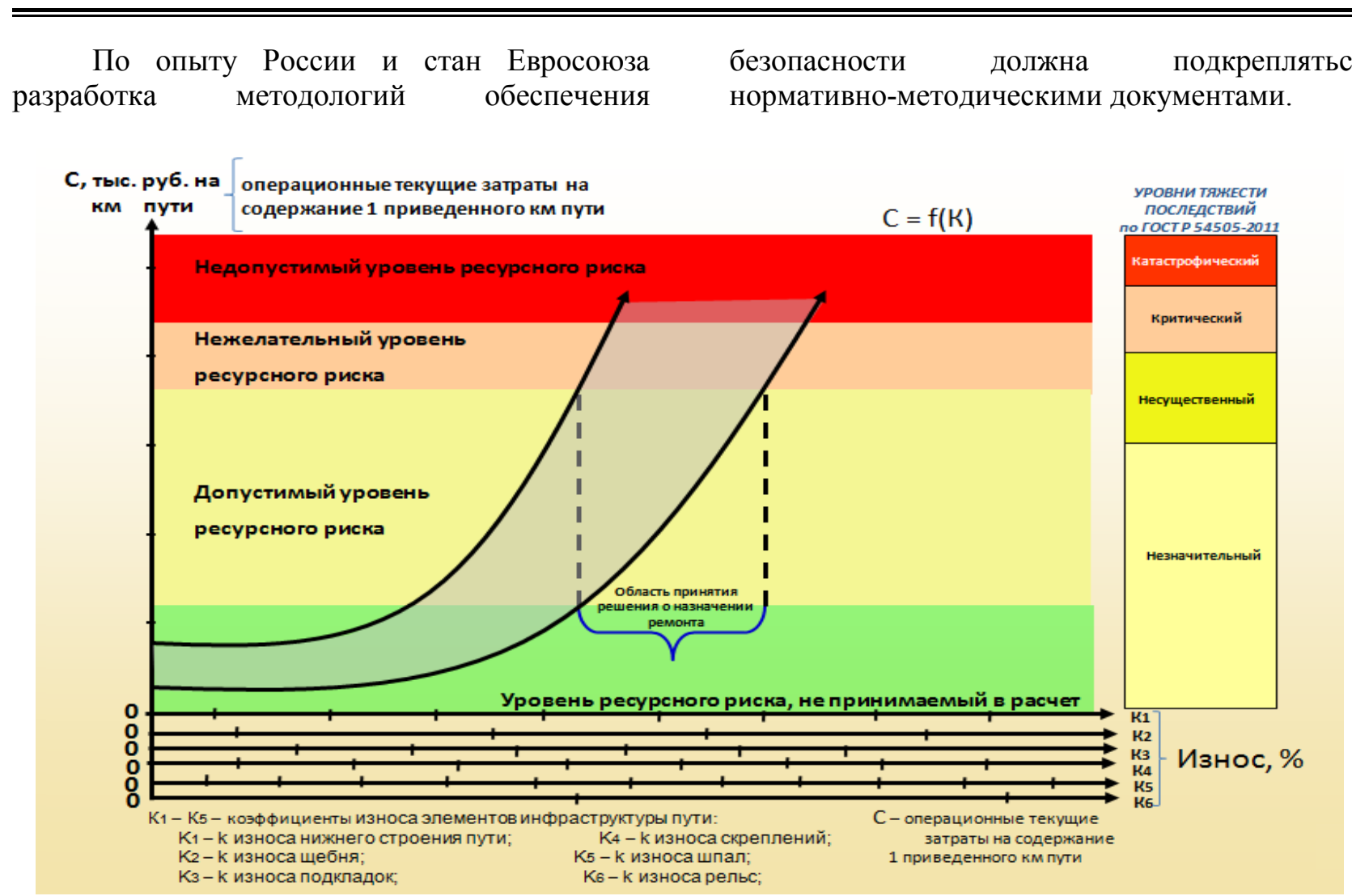

Рис. 11. Ресурсная модель оптимизации жизненного цикла железнодорожного пути на основе оценки физического износа элементов инфраструктуры

\section{Список использованных источников}

1. Транспортна стратегія України на період до 2020 року [Електронний ресурс]. - Режим доступу: http://zakon4.rada.gov.ua/laws/show/2174-2010-p.

2. Стратегия развития железнодорожного транспорта в РФ до 2030 года Утверждена Распоряжением Правительства РФ от 17 июня 2008 г. № 877-р [Электронный ресурс]. - Режим доступа: http://www.mintrans.ru/documents/detail.php?ELEMENT_ID=13009.

3. Розсоха, О.В. Аналіз функціонування системи управління безпекою руху поїздів на залізницях України [Текст] / О.В. Розсоха, М.В. Люлін, О.В. Щербина // Залізничний транспорт України. - 2013. - № 5/6. - С. 21-25.

4. Лисенков, В.М. Статистическая теория безопасности движения поездов [Текст] / В.М. Лисенков. - М., 1999. - 332 с. - (ВИНИТИ РАН).

5. Замышляев, А.М. Повышение безопасности движения на основе комплексной оценки состояния инфраструктуры железнодорожной станции [Текст]: дис... канд. техн. наук: 05.22.08/ Замышляев А.М. - М., 2005. - 291 с.

6. Замышляев, А.М. Управление техническим содержанием инфраструктуры ОАО "РЖД" на основе методологии УРРАН [Текст] / А.М. Замышляев // Презентация ОАО "НИИАС". - 2012. - 39 с.

7. Индекс инфляции (Украина) [Электронный ресурс] // Минфин. - 2015. - Режим доступа: http://index.minfin.com.ua/index/infl/.

8. Красковский, А.Е. Развитие ревизорского контроля по безопасности движения в компании ОАО "РЖД" [Текст] / А.Е. Красковский // Евразия Вести. - 2004. - №4. - С. 19-21.

9. Якунин, В.И. Стратегия инновационного развития ОАО "РЖД" на период до 2015 года (Белая книга ОАО "РЖД") [Текст] / В.И. Якунин. - М.: Транспорт, 2010. - 71 с.

10. Гапанович, В.А. Система УРРАН. Универсальный инструмент поддержки принятия решений [Текст] / В.А. Гапанович // Железнодорожный транспорт. - 2012. - №10. - С. 16-22. 


\section{Експлуатація залізниць}

11. Управление ресурсами, рисками на всех этапах жизненного цикла на основе анализа надежности УРРАН [Электронный ресурс] // Инновационный дайджест. - Режим доступа: http://www.rzd-expo.ru/innovation/accelerating_and_increasing_the_reliability_of_the_service_life_of_ facilities/resource_management_risk_to_the_life_cycle_and_reliability_analysis_of_urr/.

12. Гапанович, В.А. На основе оптимизации стоимости жизненного цикла [Текст] / В.А. Гапанович // Железнодорожный транспорт. - 2013. - №6. - С. 26-34.

Огар Олександр Миколайович, доктор технічних наук, професор, завідувач кафедри залізничних станцій та вузлів, Український державний університет залізничного транспорту. Тел.: (057) 730-10-42.

Пазойський Юрій Ошарович, доктор технічних наук, професор, завідувач кафедри залізничних станцій та вузлів, Московський державний університет шляхів сполучення. Тел.: (495) 684-23-87, (495) 684-23-93.

Розсоха Олександр Володимирович, кандидат технічних наук, доцент кафедри залізничних станцій та вузлів, Український державний університет залізничного транспорту. Тел.: (057) 730-10-42.

Сідраков Олександр Андрійович, кандидат технічних наук, доцент кафедри залізничних станцій та вузлів, Московський державний університет шляхів сполучення. Тел.: (495) 684-23-87, (495) 684-23-93.

Смачило Юлія Володимирівна, здобувач наукового ступеня кафедри залізничних станцій та вузлів,

Український державний університет залізничного транспорту. Тел.: (057) 730-10-42.

Ogar Olexandr, Professor, Doctor of technical sciences, head of the Chair «Railway Stations and Junctions», Ukraine State University of Railway Transport. Tel.: (057) 730-10-42.

Pazoysky Yuriy, Professor, Doctor of technical sciences, head of the Chair «Raillway Stations and Junctions», Moscow State University of Railway Engineering. Tel.: (495) 684-23-87, (495) 684-23-93.

Rozsokha Olexandr, Associate Professor, Doctor of Science (Ph.D.) of Chair «Railway Stations and Junctions», Ukraine State University of Railway Transport. Tel.: (057) 730-10-42.

Sydrakov Alexandr, Associate Professor, Doctor of Science (Ph.D.) of Chair «Railway Stations and Junctions», Moscow State University of Railway Engineering. Tel.: (495) 684-23-87, (495) 684-23-93.

Smachilo Julia, Applicant of the scientific degree of Chair «Railway Stations and Junctions», Ukraine State University of Railway Transport. Tel.: (057) 730-10-42.

Стаття прийнята 03.07.2015 p. 